\title{
Cecilia Meireles
}

(r90I-r964)

Ninguém falara da morte em lingua portuguêsa com tanta ternura antes de Cecília Meireles, e muito poucos poderão fazê-lo com igual intensidade depois. Ninguém dera ao diálogo do Efêmero e do Eterno um aspecto tão úbiquo, sem pretender jamais à pregação filosófica ou religiosa, mas apenas, como ela própria o definiu, "por uma contemplação poética afetuosa e participante" (entrevista a Manchete, 3-ro-53).

Poetisa profundamente consciente da tradição lírica ibérica (tantos, em 1938, quando a Academia Brasileira de Letras deu-lhe o prêmio de poesia, criticaram-na por mais ibérica que brasileira!), ela soube contribuir orginalmente para esta tradição com uma atitude de conhecimento e amizade com a morte, não estoica mas sábia, não masoquista mas integrante, que a tornou a primeira alta voz universalizante da poesia brasileira moderna.

Cecília Meireles nasceu na cidade do Rio de Janeiro em 7 de novembro de rgor. Seus ancestrais vieram dos Açores. Já órfã de pai ào nascer, a mãe morreu-lhe aos três anos; criou-a a avó materna.

Em 1917 , já é professôra primária, mas é à literatura que vai dar a melhor parte de seu interêsse pois, daí há dois anos, publica seu primeiro livro de versos, Espectros. A característica fundamental desta obra - rara e jamais reeditada - é seu espiritualismo. A poetisa carioca liga os últimos elementos de um simbolismo não de todo morto aos valôres que um grupo de intelectuais (de base principalmente católica) tentava erguer, mais ou menos em contraposição ao nacionalismo da Semana de Arte Moderna, defendendo a universalidade como única forma válida de expressão. Posteriormente, Cecilia vai se identificar ainda mais com êstes princípios, ao tomar parte na responsabilidade editorial de revistas como Arvore Nowa, Teirre de Sol e Festa (1922-1927), frutos do neo"simbolismó pré-moder- 
nista, mas já incorporando qualidades formais das novas tendências de vanguarda.

A grande poetisa, entretanto, a Cecilia Meireles que conhecemos hoje, nasce quando a editorial Império, de Lisboa, publica Viagem, em 1939. Daí até Solombra (1964) há um monólogo constante em que a morte, o homem e a possibilidade da existência de Deus representam a maior parte. Muito significativamente, ao organizar a edição de sua Obra Poética (Aguilar, I958), o primeiro livro incluido foi Viagem, esta "flor do espírito, desinteressada e efêmera", como se auto-definiu na primeira página. Vaga Música (1942), Mar Absoluto (1945), Retrato Natural (1949), 12 Notmrnos da Holanda e O Aeronauta (1952), Cançoes (1956), Metal Rosicler (1960) são alguns dos momentos dêste diálogo que ficaram marcados mais fundamente na literatura brasileira. Romanceiro da Inconfidência (1953), pelo que êle tem de madureza e sensibilidade, é o ponto mais alto de todos: uma demorada meditação sôbre o Brasil, um retrato gótico do país, em que os elementos poéticos com que convivia surgem como definidores da entidade nacional:

\section{O silenciosas vertentes por onde se precipitam inexplicáveis torrentes, por eterna escuridão!}

No Brasil, nem só como poetisa a conheciam: educadora, jornalista, folclorista, ela foi uma das figuras mais atuantes de nossa cultura. Responsável pela primeira biblioteca especializada infantil, criadora da cadeira de Literatura Luso-Brasileira e, em seguida, de Técnica e Crítica Literária na Universidade do Distrito Federal, ela fêz mais que qualquer outro escritor contemporâneo pelo conhecimento mútuo das duas mais impor. tantes literaturas em língua portuguêsa. Seu Poetas Novos de Portugal (1944) é ainda hoje a fonte básica onde vai beber quem se interessa no Brasil pelo que se pasa no Portugal contemporâneo. Pode-se mesmo afirmar que a ela deve muito a popularidade aquém mar de um Fernando Pessoa e de um Camilo Pessanha.

Conferencista e professôra, Cecília levou a cultura brasileira além das fronteiras nacionais: Portugal, Estados Unidos (professôra da Universidade do Texas), Uruguai, Argentina, India, Pôrto Rico, Israel, Europa Ocidental, em todos êstes locais ela deixou alguma marca de sua atividade. 
Ao falecer, em novembro de 1964, Cecilia Meireles havia construido uma obra literária que a iguala aos primeiros criadores da língua portuguêsa. Sua herança ("êste mar solitário, que de um lado era amor e, do outro. esquecimento") está presente em tôda a poesia brasileira contemporânea, mesmo naqueles mais impenetráveis à sua musicalidade atonal $\mathrm{e}$ às suas preocupaçōes espirituais. Na sua intuição de poeta ela o sabia, ainda que o freio da modéstia não permitisse sua afirmação total:

Minha canção não foi bela:

minha canção foi só triste.

Mas eu sei que não existe

mais canção igual àquela. 
